\title{
PENGARUH SiC TERHADAP SIFAT MEKANIK DAN MIKROSTRUKTUR PADA ALUMINIUM A356 MENGGUNAKAN PENGECORAN METODE COOLING SLOPE
}

\author{
Diki Ari Sandi ${ }^{1 *}$, Tugiman ${ }^{2}$, Indra $^{3}$, M. Sabri ${ }^{4}$, Syahrul Abda ${ }^{5}$, Mahadi $^{6}$ \\ ${ }^{1,2,3,4,5,6}$ Departemen Teknik Mesin, Fakultas Teknik, Universitas Sumatera Utara \\ Email: dikiyoe1@gmail.com
}

\begin{abstract}
Aluminum matrix composite has good mechanical properties compared to aluminum alloys without reinforcement. The type of aluminum used A356 is widely used in engineering. This study aims to determine the effect of the slope angle carried out when casting metal on mechanical properties of hardness, impact, tensile, wear and microstructure. Specimens were made using casting slope cooling methods with variations in slope angle $15^{\circ}, 30^{\circ}, 45^{\circ}, 60^{\circ}$, and $75^{\circ}$ with a pour temperature of $680^{\circ} \mathrm{C}$ and a mixture of $\mathrm{SiC} 0.5 \%$ and $2.5 \%$. The highest average hardness obtained in the $2.5 \% \mathrm{SiC}$ mixture of $30^{\circ}$ slope angle is $55.74 \mathrm{BHN}$. The highest impact energy was obtained at a mixture of $0.5 \%$ with a slope of $75^{\circ}$ which was equal to 12.87 Joules and the highest value was 0.156 Joule $/ \mathrm{mm}$. The highest impact energy was obtained at a mixture of $0.5 \%$ with a slope of $75^{\circ}$ which was equal to 12.87 Joules and the highest value was 0.156 Joule $/ \mathrm{mm}$. Wear testing is done by pin on disk method with variations in rotation of $150 \mathrm{Rpm}, 180 \mathrm{Rpm}, 210 \mathrm{Rpm}$. The highest average tensile stress of $\mathrm{Al}-\mathrm{SiC}$ material is obtained at $30^{\circ}$ slope variation that is equal to $119.91 \mathrm{Mpa}$. Microstructure results showed an increase in slope angle affecting the microstructure of Al-SiC.
\end{abstract}

Keywords: Aluminum matrix composites, slope angle, Cooling slope, $\mathrm{SiC}$, mechanical properties, microstructure

\begin{abstract}
Abstrak
Aluminium matrix composite memiliki sifat mekanis yang baik dibandingkan dengan paduan aluminium tanpa penguat. Jenis aluminium yang digunakan A356 yang banyak dipergunakan pada bidang teknik. Penelitian ini bertujuan untuk mengetahui pengaruh sudut kemiringan yang dilakukan pada saat pengecoran logam terhadap sifat mekanis kekerasan, impak, tarik, keausan dan mikrostruktur. Spesimen dibuat menggunakan pengecoran metode cooling slope dengan diberi variasi sudut kemiringan $15^{\circ}, 30^{\circ}, 45^{\circ}, 60^{\circ}$, dan $75^{\circ}$ dengan temperatur tuang $680^{\circ} \mathrm{C}$ serta campuran $\mathrm{SiC} 0,5 \%$ wt dan 2,5\%wt. Kekerasan rata-rata tertinggi diperoleh pada campuran 2,5\% wt $\mathrm{SiC}$ sudut kemiringan $30^{\circ}$ adalah 55,74 BHN. Energi impak tertinggi didapat pada campuran $0,5 \%$ wt dengan sudut kemiringan $75^{\circ}$ yaitu sebesar 12,87 Joule dan nilai tertinggi sebesar 0,156 Joule/mm. Pengujian keausan dilakukan dengan metode pin on disk dengan variasi putaran 150
\end{abstract}


Rpm, 180 Rpm, 210 Rpm. Nilai rata-rata tegangan tarik material Al-SiC tertinggi didapat pada variasi kemiringan $30^{\circ}$ yaitu sebesar 119,91 Mpa. Hasil mikrostruktur memperlihatkan peningkatan sudut kemiringan berpengaruh terhadap struktur mikro Al-SiC.

kata kunci : Aluminium matrix composites, sudut kemiringan, Cooling slope, SiC, sifat mekanis, mikrostruktur

\section{Pendahuluan}

AMC (Aluminum Matrix Composites) adalah jenis material komposit logam dengan aluminium sebagai matrik dan serbuk $\mathrm{Si}, \mathrm{Mn}, \mathrm{Ti}$ dan $\mathrm{Cu}$ sebagai penguat. AMC mempunyai prospek pengembangan yang bagus,didasari oleh sifat-sifatnya yang baik, seperti kekerasan dan kekuatan yang tinggi, mampu mesin yang baik, densitas yang rendah, bahan dasar yang mudah didapatkan, dengan harga yang ekonomis dan bersaing dengan material lain. AMC banyak dimanfaatkan pada bidang industri otomotif, penerbangan,dan pertahanan sebagai bahan kendaraan tempur yang membutuhkan performa tinggi. AMC bisa diaplikasi dalam permesinan pesawat terbang, dan aplikasi dalam industri otomotif.

Penelitian mengenai komposit matrik aluminium telah banyak dilakukan, namun dari uraian diatas diketahui bahwa penggunaan cooling slope masih sangat terbatas. Berdasarkan hal tersebut maka pada penelitian ini dilakukan pembuatan komposit menggunakan pengecoran metode cooling slope pada berbagai kemiringan serta mengetahui pengaruh $\mathrm{SiC}$ terhadap sifat mekanik, Seperti pengujian kekerasan, mikrostruktur dan laju keausan.

\section{Bahan dan Metode}

Pada penelitian ini digunakan aluminium A356 ditambah 1,5\%wt dan 2.5\%wt SiC. Proses pencairan aluminium alloy dilakukan menggunakan dapur peleburan berbahan bakar arang kayu laut menggunakan wadah crusibel grafit. Penuangan cairan aluminium alloy diperkuat $\mathrm{Si} / \mathrm{SiC}$ dilakukan pada suhu $680 \mathrm{oC}$. Penuangan dilakukan ke permukaan pelat cooling slope dengan kemiringan 15, 30, 45, 60 dan 75o sesaat sebelum memasuki cetakan permanen. Cetakan berbentuk silinder dibuat dari bahan mild steel digunakan untuk pembuatan spesimen uji aus, mikrostruktur, dan kekerasan. Pengujian aus dibuat menggunakan metode pin on disc dengan spesimen uji berbentuk pelat, uji aus dilakukan kondisi kering (dry sliding) pada kecepatan sliding 150, 180 dan 210 rpm serta beban $5 \mathrm{~N}$ selama 0.5 menit.

Pada pengecoran kali ini di tambah komponen peralatan yaitu cooling slope. Peralatan ini berfungi sebagai control cooling rate pada cairan logam sebelum mengisi rongga cetakan. Pada peralatan ini pengaturan dilakukan terhadap kemiringan plat dan panjang lintasan cairan, dimana kedua faktor ini sangat menentukan laju pendinginan cairan sebelum mengisi cetakan.berikut adalah gambar peralatan cooling slope. 


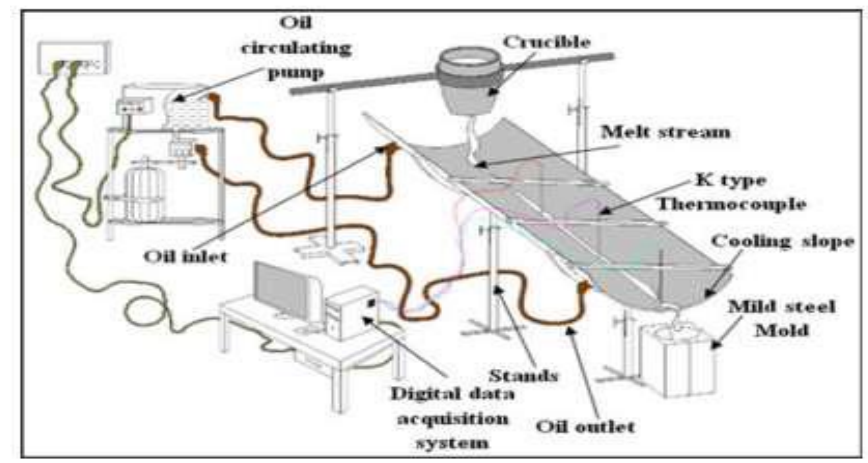

Gambar 2.1. Skema peralatan cooling rate

\section{Hasil dan Pembahasan}

\subsection{Hasil pengujian mikrostruktur}
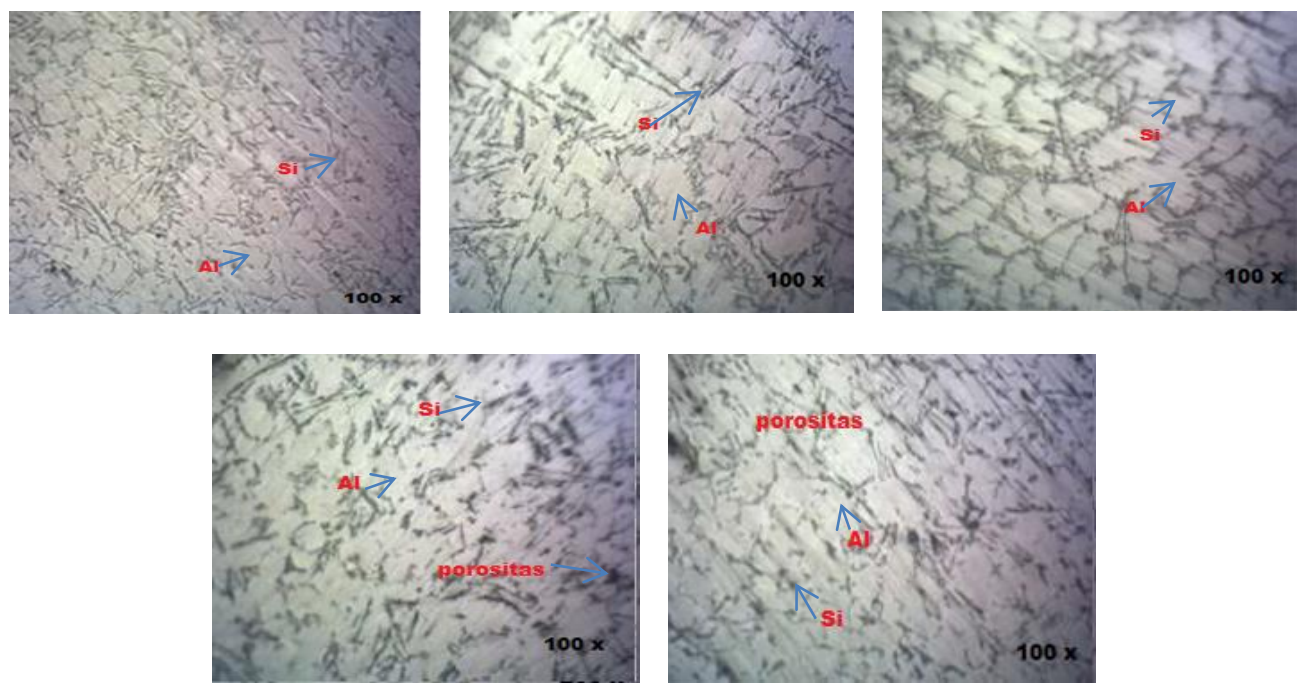

Gambar 3.1 foto mikrostruktur kemiringan (a) $15^{\circ}$ (b) $30^{\circ}$ (c) $45^{\circ}$ (d) $60^{\circ}$ dan (e) $75^{\circ}$ dengan komposisi 0,5\%wt $\mathrm{SiC}$.

Pada gambar 3.1 (a)-(e) terlihat struktur mikro yang terbentuk dengan pembesaran 100x, menunujukan struktur acircular -Al (berwarna terang) dan Strukur eutectic silicon (berwarna gelap). pada penelitian ini juga ditemukan porositas ( tanda panah biru ) yang tentunya dapat menurunkan kekuatan bahan. hal tersebut dapat dipengaruhi oleh faktor laju pendinginan.pada struktur ini menunjukan kerapatan butiran $\mathrm{SiC}$ yang dapat meningktkan kekeresan.
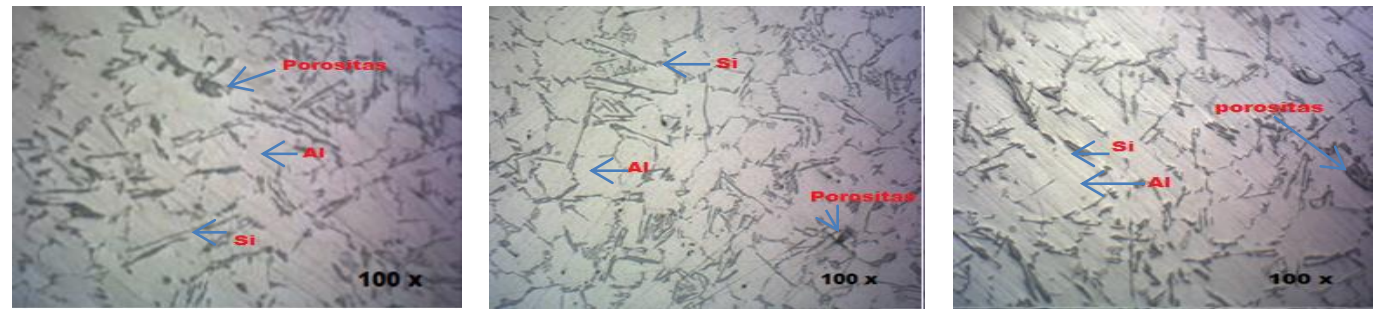

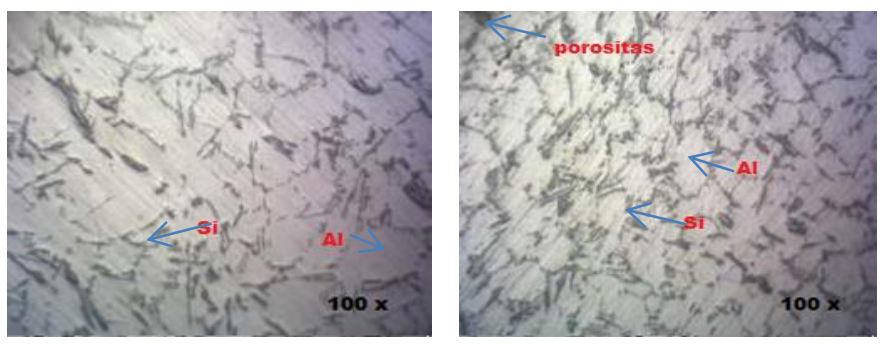

Gambar 3.2 foto mikrostruktur kemiringan (a) $15^{\circ}$ (b) $30^{\circ}$ (c) $45^{\circ}$ (d) $60^{\circ}$ dan (e) $75^{\circ}$ dengan komposisi 2,5\%wt $\mathrm{SiC}$.

Gambar diatas memperlihatkan struktur mikro aluminium pada kemiringan cooling slope $30^{\circ}$ terdiri dari dua area dengan warna yang berbeda. -Al berwarna cerah berperan sebagai matrik dengan ukuran cukup besar $\pm 100-200 \mu \mathrm{m}$. Sementara partikel-partikel $\mathrm{Si} / \mathrm{SiC}$ yang memiliki melting point lebih tinggi cenderung terdispersi diantara matrik tersebut, hal ini dikarenakan kedua elemen $\mathrm{Al}$ dan $\mathrm{Si} / \mathrm{SiC}$ memiliki perbedaan titik cair yang sangat berbeda menyebabakan sulit terbentuk solid solution pada suhu ruang sehingga penguatan yang terjadi melaluimekanisme dispertion strengthening.

\subsection{Hasil pengujian Kekerasan}

Pengujian kekerasan dilakukan menggunakan standart pengujian E10-01. menggunakan metode pengujian Brinell dengan beban sebesar $500 \mathrm{~kg}$ selama 5 detik.

Tabel nilai rata-rata $\mathrm{BHN} 2,5 \%$ wt $\mathrm{SiC}$ dan $0,5 \%$ wt $\mathrm{SiC}$

\begin{tabular}{|c|c|c|}
\hline \multirow{2}{*}{ variasi sudut } & \multicolumn{2}{|c|}{ BHN Rata-rata } \\
\cline { 2 - 3 } & \multicolumn{2}{|c|}{$\mathbf{A 3 5 6}$} \\
\hline & $\mathbf{2 , 5} \% \mathbf{~ S i C}$ & $\mathbf{0 , 5} \% \mathbf{~ S i C}$ \\
\hline 15 & 51,81 & 51,56 \\
\hline 30 & 55,74 & 50,16 \\
\hline 45 & 52,10 & 49,91 \\
\hline 60 & 50,08 & 48,69 \\
\hline 75 & 49,09 & 48,23 \\
\hline
\end{tabular}

Tabel 4.3 menunjukan nilai Brinell Hardness Number (BHN) dari hasil Pengujian kekerasan Nilai rata-rata BHN dengan perbandinga komposisi SiC 2,5\%wt dan 0,5\%wt. dengan perbedaan komposisi $\mathrm{SiC}$ ini dapat mengetahui komposisi campuran $\mathrm{SiC}$ yang terbaik dan kemiringan slope yang terbaik .

Gambar 3.3 memperlihatkan bahwa pengaruh komposisi pada pembuatan Aluminium matrik komposit dapat meningkatkan nilai kekerasan (BHN).pada pengecoran ini nilai rata-rata maksimum di capai pada sample kemiringan slope 30 derajat dan campuran $\mathrm{SiC}$ 2,5\%wt yaitu sebesar 55,74 BHN.sedangkan nilai kekerasan terendah pada kemiringan slope 75 derajat dengan komposisi $\mathrm{SiC} 2.5 \%$ wt yaitu sebesar 49,09 BHN. kemiringan slope dapat mempengaruhi nilai kekerasan. Laju logam cair pada kemiringan hingga jatuh ke cetakan sangat berpengaruh. 


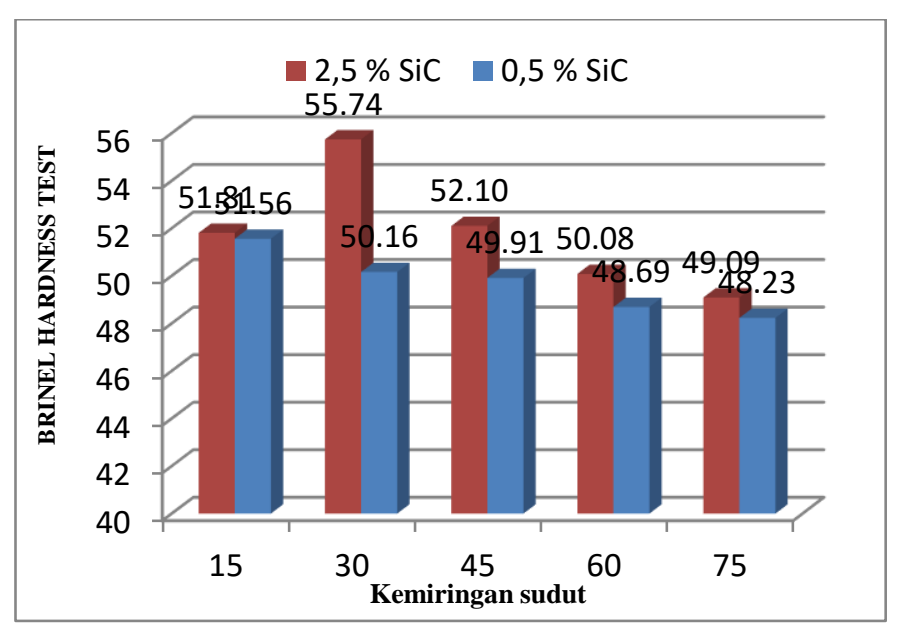

Gambar 3.3 Grafik Kekerasan nilai rata-rata 2,5\%wt dan 0,5\%wt SiC

Hasil pengujian kekerasan brinnel terhadap dua jenis sampel dengan komposisi partikel $\mathrm{SiC}$ yang berbeda, penambahan partikel terseebut berhasil meningkatkan kekerasan bahan. Terlihat pada komposisi $0,5 \%$ wt $\mathrm{SiC}$ nilai kekerasan tertinggi 51,81 BHN ,sedangkan pada komposisi 2,5\% wt SiC nilai kekerasan tertinggi yaitu 55,74 BHN ,hal ini menunjukan keberhasilan peningkatan komposisi $\mathrm{SiC}$ dapat meningkatkan kekerasan.Penggunaan pengecoran gravitasi memiliki kelemahan dalam hal mencapai kehomogenan yang baik .

\subsection{Hasil pengujian Impact}

Pengujian impak dilakukan pada sampel uji menggunakan metode charpy dan menggunakan standart pengujian dari Annual book of ASTM Vol.14.01E23M-00a dengan panjang $55 \mathrm{~mm}$ tinggi $10 \mathrm{~mm}$ dan lebar $10 \mathrm{~mm}$.

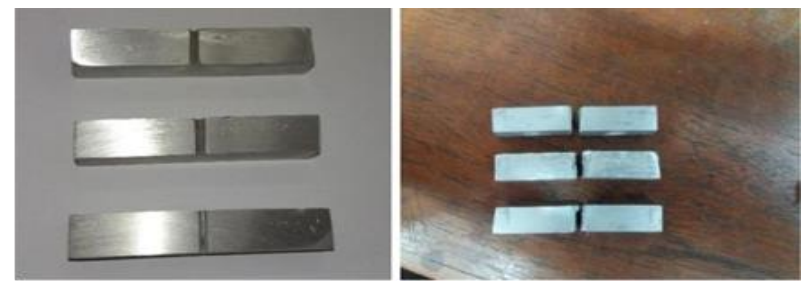

Gambar 4.4 Spesimen impact sebelum dan sesudah di uji

Tabel Hasil uji impact nilai impact

\begin{tabular}{|l|l|l|l|l|l|l|}
\hline \multirow{2}{*}{ sudut } & \multicolumn{2}{l|}{ Daerah } & \multicolumn{2}{l|}{ Daerah } & \multicolumn{2}{l|}{ Nilai Impak (Joule/mm²) } \\
\cline { 2 - 7 } & $\mathbf{0 . 5 \%}$ SiC & \multicolumn{2}{l|}{$\mathbf{2 . 5 \%}$ SiC } & \multicolumn{2}{l|}{ Nilai rata-rata } \\
\cline { 2 - 7 } & Atas & Bawah & Atas & Bawah & A356+0.5\%SiC & A356+2.5\% SiC \\
\hline 15 & 0,070 & 0,090 & 0,097 & 0,083 & 0,080 & 0,090 \\
\hline 30 & 0,104 & 0,090 & 0,059 & 0,080 & 0,097 & 0,070 \\
\hline 45 & 0,104 & 0,090 & 0,108 & 0,084 & 0,097 & 0,096 \\
\hline
\end{tabular}




\begin{tabular}{|l|l|l|l|l|l|l|}
60 & 0,106 & 0,120 & 0,123 & 0,081 & 0,113 & 0,102 \\
\hline 75 & 0,142 & 0,170 & 0,125 & 0,121 & 0,156 & 0,123 \\
\hline
\end{tabular}

Dari tabel 4.5 menunjukan bahwa hasil uji impak pada kedua sample 0,5\%wt dan 2,5\%wt SiC . Maka nilai impak sample uji tersebut dapat dibuat dalam grafik akan terlihat seperti gambar 4.8. menunjukan nilai impak tertinggi pada komposisi 0,5\% wt SiC pada sudut kemiringan $75^{\circ}$ yaitu $0,156(\mathrm{~J} / \mathrm{mm} 2)$ dan nilai terendah pada kemiringan $15^{\circ}$ yaitu $0,080(\mathrm{~J} / \mathrm{mm} 2)$.sehingga dapat dilihat dari patahan uji sample gambar 4.9 smpai 4.14 merupakan patah getas.

\subsection{Hasil pengujian Aus}

Pengujian keausan dilakukan dengan metode pin on disk standart ASTM G99-04 dengan variasi beban dan kecepatan putaran. Keausan yang terjadi pada pengujian ini adalah keausan abrasive (Abrasive wear). Pada pengujian keausan ini kecepatan putaran di variasikan $(\mathrm{n})=150,180$ dan $210 \mathrm{rpm}$ waktu $(\mathrm{t})=30 \mathrm{~s}$ dan pembebanan $5 \mathrm{~N}$ adalah konstan. Berikut spesimen uji keausan dapat dilihat pada gambar.
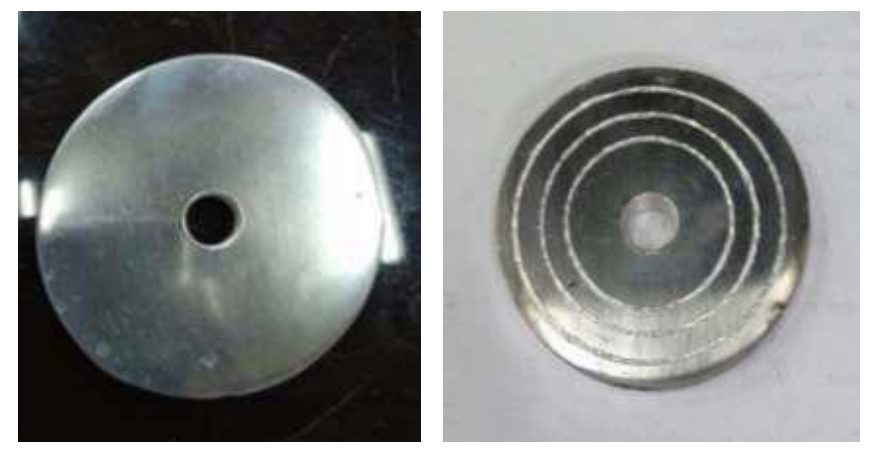

Gambar 3.5 uji aus metode pin on disk (a) sebelum di uji, (b) setelah pengujian

Foto sampel lebar jejak dan kedalama uji keausan diperlihatkan pada gambar berikut ini :
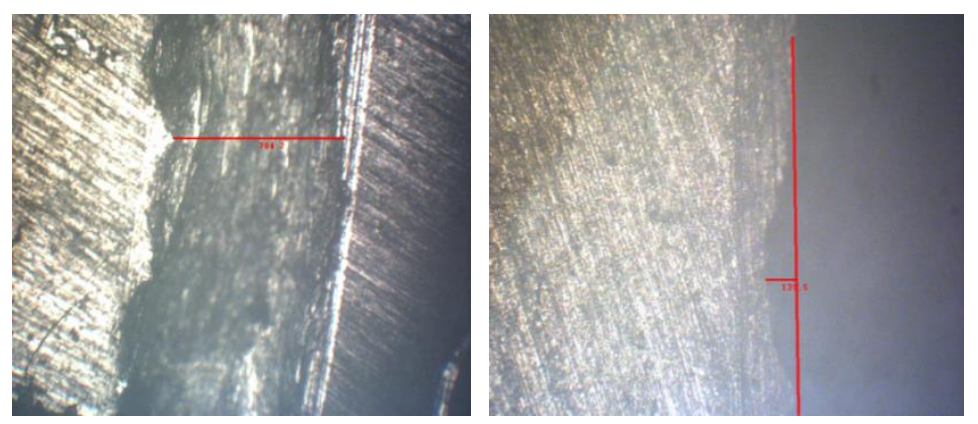

Gambar 3.6 foto sample lebar dan kedalam Uji Aus.

Laju keausan bahan sangat dipengaruhi oleh kecepatan sliding disk serta jenis bahan yang diuji. Gambar 3.7 memperlihatkan untuk hampir semua kemiringan cooling slope peningkatkan kecepatan akan meningkatkan laju keausan bahan. Laju keausan tertinggi diperoleh pada $210 \mathrm{rpm}$ untuk bahan dengan kemiringan slope $75^{\circ}$. Sebaliknya laju 
keausan terendah diperoleh pada bahan dengan kemiringan sudut $30^{\circ}$ kecepatan sliding $150 \mathrm{rpm}$.

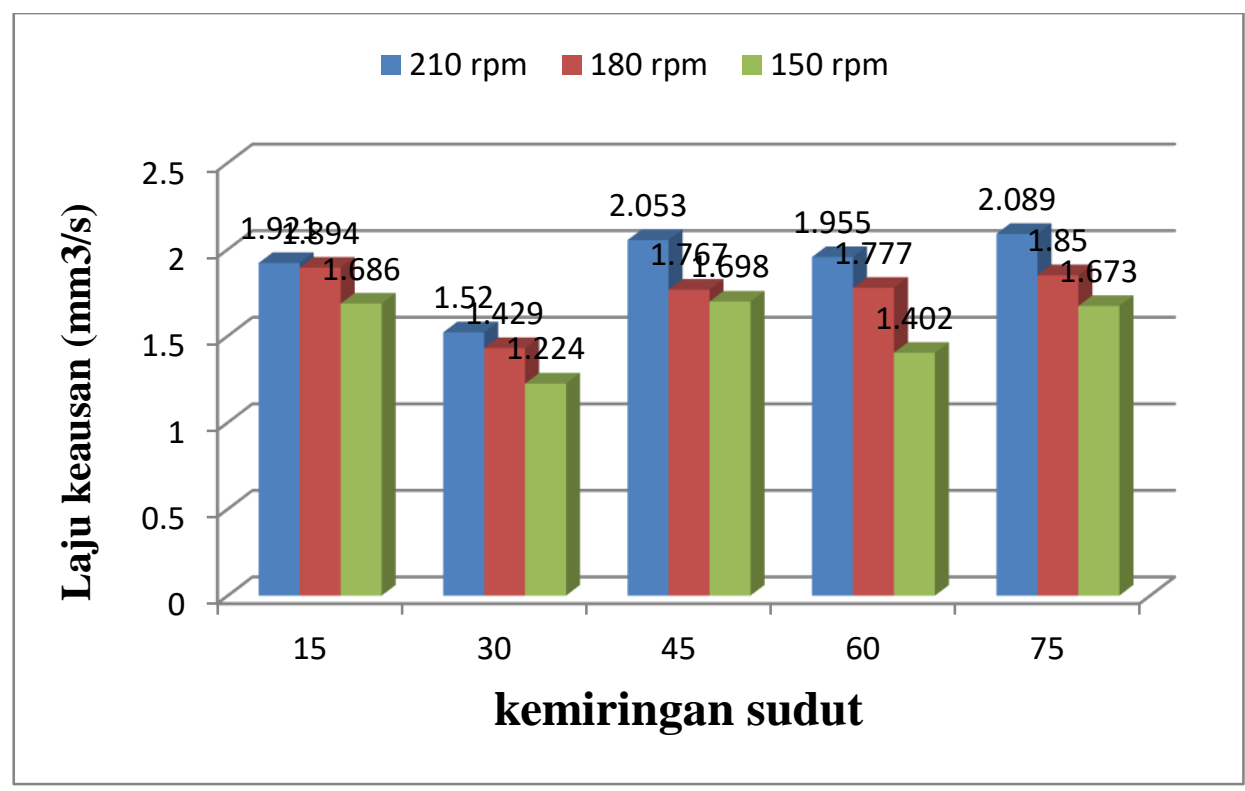

Gambar 3.7 Laju keausan bahan alumunium-0.5\%wt. SiC pada berbagai kecepatan sliding

Gambar 3.8 memperlihatkan laju keausan tertinggi bahan diperoleh pada putaran 210 rpm dengan kemiringan slope $45^{\circ}$, dan sebaliknya laju keausan terendah secara umum diperoleh pada putaran $150 \mathrm{rpm}$ dengan kemiringan slope $15^{\circ}$. grafik diatas juga memperlihatkan adanya ketidakstabilan laju keausan dengan kemiringan slope, hal ini sangat erat kaitan dengan kekerasan masing-masing sampel uji. Disamping hal tersebut, pada pengujian metode pin on disk terjadinya vibrasi saat sliding sangat dihindarkan karena vibrasi yang berlebihan akan menyebabkan lebar lintasan pengaus akan tidak konsisten sehingga dapat mempengaruhi laju keausan.

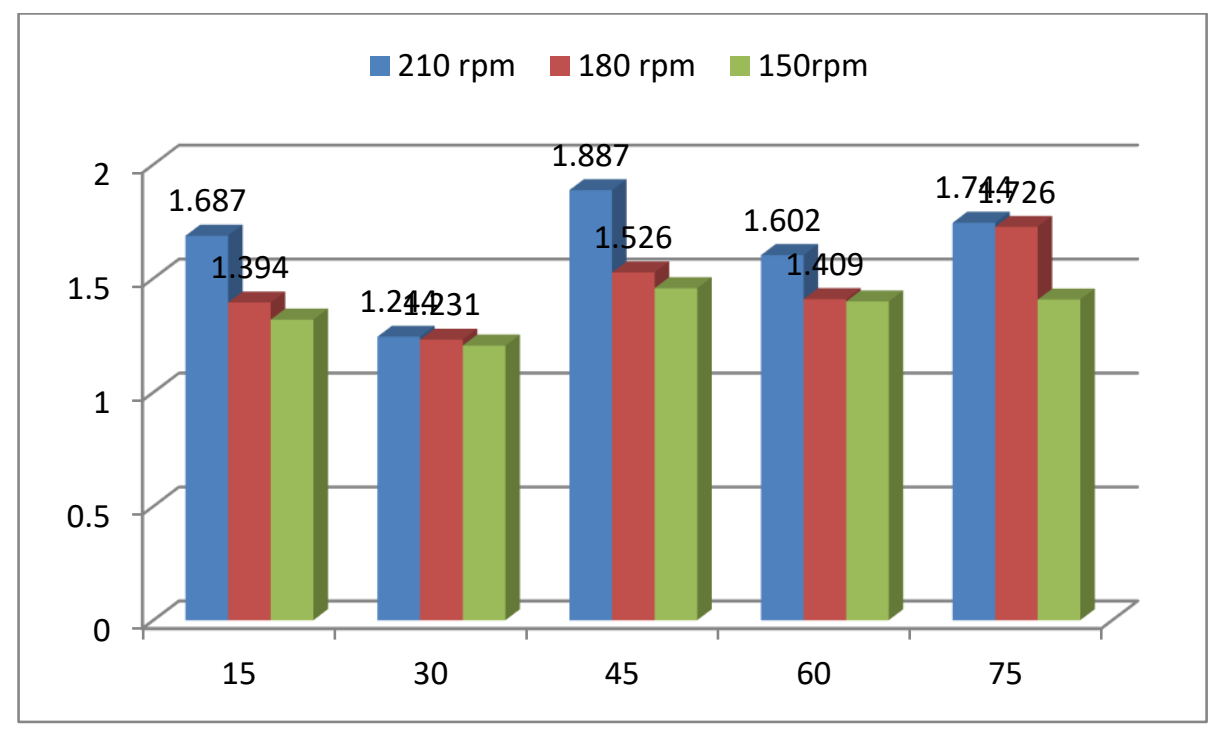

Gambar 3.8 Laju keausan bahan alumunium-2.5\%wt SiC pada berbagai kecepatan sliding 


\subsection{Hasil pengujian Tensile}

Bentuk dari spesimen pengujian tarik sudah mempunyai standar dengan menggunakan standar dari Annual book of ASTM Vol.3 E8M-00b. Foto sampel uji tensile terlihat pada gambar 4.44 pada alumunium matriks komposit A356 dengan komposisi 2,5\% wt dan $0,5 \%$ wt SiC. Standar yang digunakan untuk tarik ini adalah ASTM E8M-00b Panjang awal spesimen uji (Lo) adalah $60 \mathrm{~mm}$, lebar awal (Wo) adalah 12,5 mm, dan panjang keseluruhan spesimen uji adalah $200 \mathrm{~mm}$.

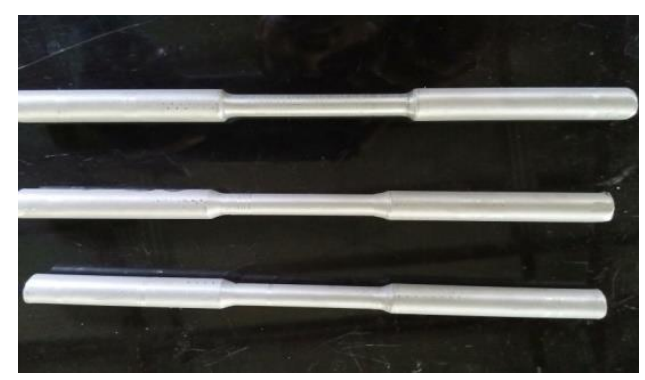

Gambar 3.9 Spesimen Uji tarik sebelum

a. Tegangan tarik A356-2,5\%wt SiC

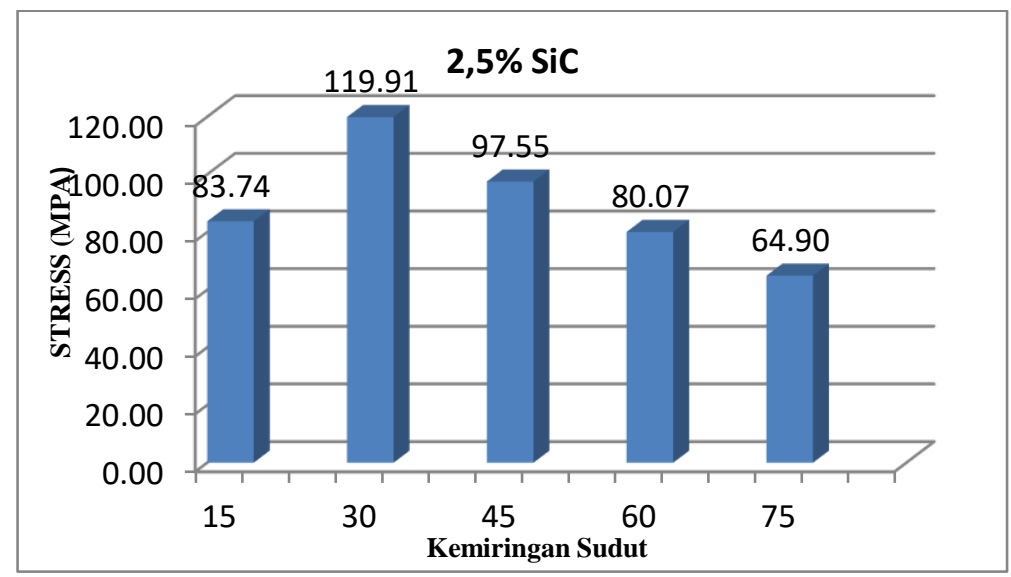

Gambar 3.10 Ultimate tensile strength (UTS) alumunium-SiC 2,5\%

Dari Gambar 3.10 hasil pengujian tensile dengan komposisi 2,5\%wt SiC dapat dilihat nilai tegangan Tertinggi yaitu pada sudut kemiringan slope $30^{\circ}$ dengan $119,91 \mathrm{MPa}$ sedangkan untuk nilai tegangan tarik terendah pada kemiringan slope $75^{\circ}$ dengan nilai 64,90 Mpa. Terlihat pada sudut $75^{\circ}$ memiliki tegangan tarik paling rendah .meningkatnya nilai tegangan tarik juga di pengaruhi dari penambahan $\mathrm{SiC}$ dari $0,5 \% \mathrm{wt}$ menjadi $2,5 \% \mathrm{wt}$ .pengaruh $\mathrm{SiC}$ dapat dilihat dari grafik bahwa nilai tegangan maksimum pada $0,5 \%$ wt adalah 81,87 Mpa dan untuk 2,5\%wt $\mathrm{SiC}$ adalah 119,91 Mpa .dapat dilihat bahwa pengaruh kemiringan juga dapat menurunkan nilai tegangan pada spesimen.

b. Tegangan tarik A356-0,5\%wt SiC

Hasil pengujian seperti diperlihatkan pada gambar 3.11. pada gambar memperlihatkan kekuatan tegangan tarik maksimum untuk paduan al-SiC diperoleh sebesar $81,87 \mathrm{Mpa}$ 
pada kemiringan slope $15^{0}$ dengan komposisi $0,5 \%$ wt SiC.Sebaliknya kekuatan terendah di peroleh pada kemiringan slope $75^{\circ}$ dengan nilai tarik maksimum sebesar $62,88 \mathrm{Mpa}$ .Hal ini dikarenakan saat pengadukan tidak merata dapat menyebabkan porositas sehingga menurunkan kekuatan tarik pada spesimen yang di uji.

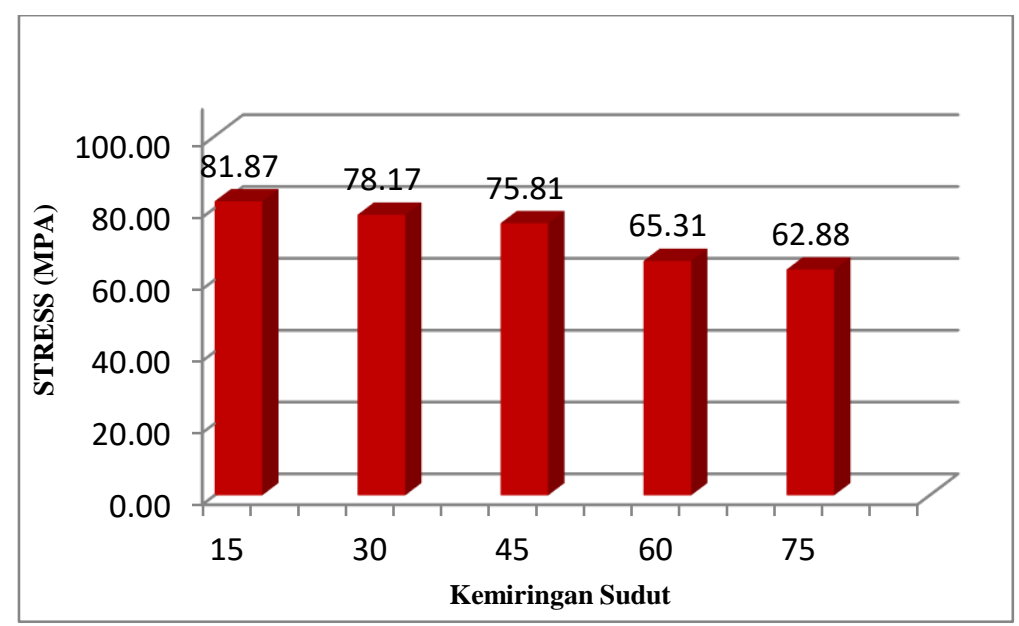

Gambar 3.11 Ultimate tensile strength (UTS) alumunium-SiC 0,5\%wt

\section{Kesimpulan}

1. Penambahan $\operatorname{SiC}(0,5 \% \mathrm{wt})$ dan $(2,5 \% \mathrm{wt})$ terhadap sifat mekanik A356 pada nilai kekerasan dapat meningkatkan kekerasan dimana nilai kekerasan tertinggi pada campuran SiC 2,5\%wt dengan nilai 55,74 BHN pada sudut $30^{\circ}$,namun pada nilai impak penambahan $\mathrm{SiC} 0,5 \%$ wt menjadi $2,5 \%$ wt untuk uji impak nilai energi yang di serap semakin menurun,untuk hasil pengujian tarik semakin bertambahnya variasi SiC dari $0,5 \%$ wt menjadi $2,5 \%$ wt maka kekutan tariknya semakin meningkat dimana hasil variasi 2,5\% wt kekutan tarik maksimum sebesar 119,91 Mpa pada kemiringan slope $30^{\circ}$.

2. Laju keausan bahan meningkat seiring dengan kecepatan sliding disk serta jenis bahan yang diuji.semakin keras bahan yang di uji maka laju keasusan nya semakin rendah,laju keausan tertinggi dari komposisi $0,5 \% \mathrm{SiC}$ diperoleh pada putaran $210 \mathrm{rpm}$ dengan kemiringan slope $45^{\circ}$, dan sebaliknya laju keausan terendah secara umum diperoleh pada putaran $150 \mathrm{rpm}$ dengan kemiringan slope $15^{\circ}$.laju keausan juga berhubungan dengan nilai kekerasan benda yang di uji .

\section{Referensi}

[1]. Suyanto, 2015, "Analisa Ketangguhan Komposit Alumunium Berpenguat Serbuk SiC”. Teknik Bangunan Kapal ,Akademi Teknik Perkapalan (ATP) ,Veteran Semarang.

[2]. Tugiman , dkk, 2017, "The effect of cooling slope on mechanical properties of aluminum-8.5wt.\%Si alloy produced by gravity casting”. Departemen Teknik, Jurusan Teknik mesin, Universitas Sumatra Utara.

[3] Monir. A , Mahmod.T.S, dkk ,'Optimization of the cooling slope casting parameters for producing aa7075 wrought aluminumalloy thixotropic 
feedstock" . Mechanical Engineering Department, Faculty of Engineering, Benha University, Cairo.

[4]. Sahini, D., Mandal, A., Chakraborty, M. 2014. Cooling Slope Casting Process of Semi - solid Aluminum Alloys: A Review. International Journal of Engineering Research \& Technology (IJERT). Vol. 3 Issue 7, July - 2014.

[5]. Tugiman, T.Awaludin, A.Farida, B.S. Tulus, Suhandi, Rizki. 2018 "The effect of cooling slope on mechanical properties of alumunium 8,5wt \% Si alloy produced by gravity casting". Journal of The $2^{\text {nd }}$ ACIEVE 2018. 